\title{
DETEKSI EKTOPARASIT Argulus sp. PADA BUDIDAYA IKAN KARPER (Cyprinus carpio L) DI UPTD- BALAI PENGEMBANGAN BUDIDAYA IKAN AIR TAWAR AIKMEL KABUPATEN LOMBOK TIMUR
}

\author{
Baiq Dini Alpi Nurani ${ }^{1}$, Alfiana Laili Dwi Agustin ${ }^{1}$, Kholik ${ }^{1}$, Kunti Tirtasari ${ }^{1 *}$ \\ ${ }^{1}$ Fakultas Kedokteran Hewan, Universitas Pendidikan Mandalika \\ *Email: kunti.tirtasari@gmail.com
}

\begin{abstract}
Argulus sp. is a fish louse disease that attacks fish on the outside of the body (Ectoparasites) resulting in wounds and bite marks being a trigger factor for the onset of other diseases (secondary diseases) resulting in losses for fish farmers. This research aims to find out if it detected Argulus ectoparasites sp in carper fish cultivation (Cyprinus carpio,L) in UPTD-BPBIAT Aikmel. This study uses a descriptive study design with observational survey type. Fish sampling is carried out using random sampling in one shot using a net with a total of 10 samples. Ectoparasite examination is carried out by making a direct observation then carried out the examination of the head, fins, tail with Alcohol Swabs 70\%, and then examined the parasites in the microscope with $4 x$ magnification. The research results shows that 9 fish were positive infectedwith Argulus sp.
\end{abstract}

Keywords : Carp, Ectoparasites, Argulus sp.

\section{PENDAHULUAN}

Usaha budidaya ikan air tawar di Indonesia merupakan salah satu usaha perikanan yang sangat potensial (Juniarsih, 2017). Ikan Karper (Cyprinus carpio L) merupakan salah satu spesies ikan air tawar yang memiliki peluang pengembangan budidaya yang besar dan merupakan jenis ikan konsumsi yang sangat disukai oleh masyarakat karena rasa dagingnya enak, tebal, empuk dan bergizi tinggi (Wihardi, 2014). Kendala yang dapat mempengaruhi tingkat keberhasilan budidaya ikan Karper adalah adanya penyakit terutama disebabkan oleh parasit. Argulus sp. merupakan salah satu organisme parasit yang menyerang ikan pada bagian luar tubuh dan bertindak sebagai ektoparasit (Ode, 2012). Infeksi parasit ini dapat mengakibatkan ikan mengalami penurunan berat badan, lemah, terjadi pendarahan dan adanya infeksi sekunder (Komarudin, 1987).

Ikan Karper di Unit Pelaksana Teknis Daerah (UPTD) Balai Pengembangan Budidaya Ikan Air Tawar (BPBIAT) Aikmel sebanyak 154 ekor. Menurut Laporan produksi dan distribusi di UPTD-BPBIAT Aikmel Tahun 2019 menunjukkan mortalitas pada benih ikan karper mencapai 48.730 ekor. Penelitian Juniarsih (2017) juga menunjukkan mengenai infeksi Argulus sp. pada ikan mas (Cyprinus carpio L) dapat mencapai prevalensi hingga $27 \%$.

Infeksi parasit menjadi permasalahan bagi pembudidaya ikan Karper karena dapat menghambat pertumbuhan ikan Karper bahkan kematian. Menurut Kurniawan (2012) Argulus sp. merupakan salah satu parasit yang banyak ditemukan menyerang ikan air tawar. Kerugian akibat dari infeksi ektoparasit memang tidak sebesar kerugian yang diakibatkan oleh infeksi organisme lain seperti virus dan bakteri, namun infeksi ektoparasit Argulus sp. dapat menjadi salah satu faktor pemicu infeksi sekunder bagi organisme pathogen yang lebih berbahaya sehingga perlu dilakukannya deteksi ektoparasit Argulus sp agar dapat segera dilakukan pengobatan dengan tepat. Berdasarkan permasalahan di atas, maka penelitian mengenai deteksi ektoparasit Argulus sp. pada Budidaya ikan Karper di UPTD- Balai Pengembangan Budidaya ikan air tawar Aikmel perlu dilakukan.

\section{MATERI DAN METODE}

Penelitian ini menggunakan penelitian studi deskriptif dengan tipe studi Observasional Survey, Penelitian dilakukan pada bulan Februari 2020 di UPTD-Balai Pengembangan Budidaya Ikan Air Tawar Kecamatan Aikmel Kabupaten Lombok Timur sebagai tempat pengambilan sampel. 
Populasi ikan karper di UPTD-BPBIAT sebanyak 154 ekor dengan jumlah sampel sebanyak 10 ekor, besaran sampel yang digunakan dalam penelitian ini

$$
\mathrm{n}=\left[1-(1-\mathrm{a})^{1 / \mathrm{d}}[\mathrm{N}-[(\mathrm{d}-1) / 2]\right.
$$

keterangan:

$\mathrm{n}=$ jumlah sampel ikan Karper

$\mathrm{d}=$ nilai hewan yang sakit, $27 \%$ dikalikan jumlah populasi ikan karper 154 (41.58)

$\mathrm{N}=$ jumlah populasi ikan Karper (154)

$\mathrm{a}=$ tingkat kepercayaan $95 \%$

$$
\begin{gathered}
\mathrm{n}=\left[1-(1-\mathrm{a})^{1 / \mathrm{d}}[\mathrm{N}-[(\mathrm{d}-1) / 2]\right. \\
\mathrm{n}=\left[1-(1-95 \%)^{1 / 41.58}\right][154-[(41.58-
\end{gathered}
$$

1)/2]

$$
\begin{aligned}
& \mathrm{n}=\left[1-(1-0.95)^{0,024}\right][(154-20.29)] \\
& \mathrm{n}=(1-0.93)(133.71) \\
& \mathrm{n}=9.3597 \\
& \mathrm{n}=10 \text { ekor }
\end{aligned}
$$

Sampel diambil pada pagi hari menggunakan jaring, Sampel diambil sebanyak 10 ekor dari 2 kolam yaitu kolam jantan dan betina masing-masing sebanyak 5 ekor, dilakukan pengusapan dengan menggunakan alcohol swabs $70 \%$, Parasit yang didapatkan dimasukkan ke dalam botol sampel yang berisi air dan telah diberi kode $\mathrm{C} 4$ dan C5, selanjutnya dibawa ke laboraturium. Sampel diambil sebanyak 1 kali pengambilan. Hasil data ini disajikan secara Deskriptif dengan menampilkan jumlah ikan Karper yang terserang ektoparasit Argulus sp. untuk melihat tingkat kejadian ektoparasit Argulus sp. yang ditemukan pada ikan Karper di UPTD-Balai Pengembangan Budidaya Ikan Air Tawar Aikmel.

\section{HASIL}

Hasil penelitian terhadap total ikan Karper sebanyak 10 ekor yang diambil dari dua kolam yaitu kolam jantan dan kolam betina masingmasing sebanyak 5 ekor dari kolam UPTDBPBIAT Aikmel Kabupaten Lombok Timur. Pengambilan sampel dilakukan secara acak ditemukan ektoparasit Argulus sp. yang menginfestasi ikan Karper (Cyprinus carpio L) (Gambar 4.1). Ikan Karper yang terinfestasi Argulus sp. pada kolam C4 dan C5 dapat dilihat pada tabel 1 .
Tabel 1. Ikan Karper yang terinfestasi Argulus sp pada kolam C4 dan C5 di UPTDBPBIAT Aikmel Kabupaten Lombok Timur

\begin{tabular}{lllll}
\hline No & Kolam & $\begin{array}{l}\text { Jumlah Ikan } \\
\text { yang diperiksa }\end{array}$ & $\begin{array}{l}\text { Hasil } \\
(+/-)\end{array}$ \\
\hline 1 & C4 4 & 5 ekor & $4 / 1$ \\
\hline 2 & C5 & 5 ekor & $5 / 0$ \\
\hline
\end{tabular}

Keterangan : C4 : Kolam Jantan C5 : Kolam Betina

Berdasarkan hasil penelitian ektoparasit pada ikan Karper (Cprynus carpio L) terlihat seperti kutu yang menempel pada bagian luar tubuh ikan dengan ukuran panjang rata-rata pada kolam C4 dan C5 1,70 mm Gambar 4.1 Argulus sp. di UPTD-BPBIAT Aikmel terlihat seperti adanya lempengan berbentuk lonjong pada bagian dorsal yang melindungi thoraks dan hampir menutupi sebagian tubuhnya yang disebut juga karapas, terdapat 3 bagian tubuh yaitu chepalotorax terdapat 2 pasang maxilla untuk menghisap inang, bagian thorax terdapat 3 segmen dan setiap segmennya terdapat sepasang kaki untuk berenang, dan bagian abdomen terlihat seperti ekor yang menggantung. Faktor pemicu timbulnya Argulus sp salah satunya adalah iklim dan biasanya terjadi pada musim hujan. Infeksi parasit Argulus sp. mengakibatkan ikan Karper di UPTD-BPBIAT Aikmel mengalami luka pada sirip, ekor dan permukaan tubuh seperti pada gambar 2 dan 3 .

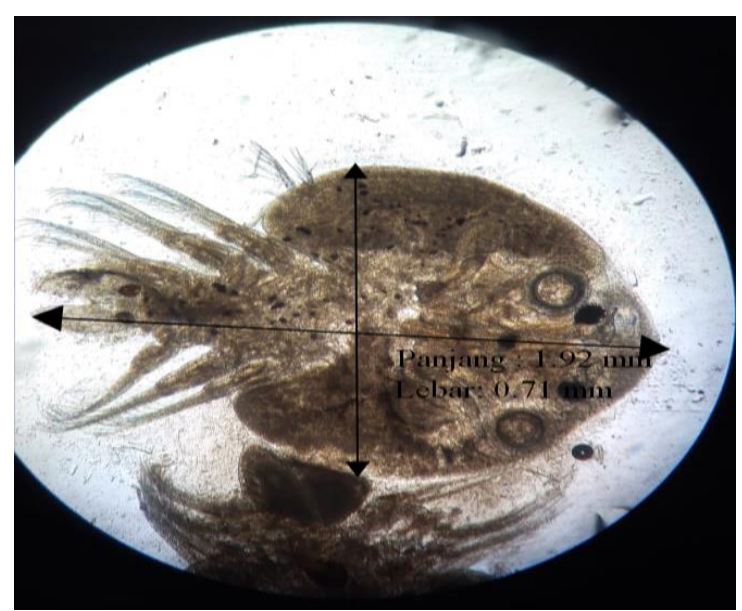

Gambar 1. Argulus sp dengan mikroskop perbesaran $4 x$ 

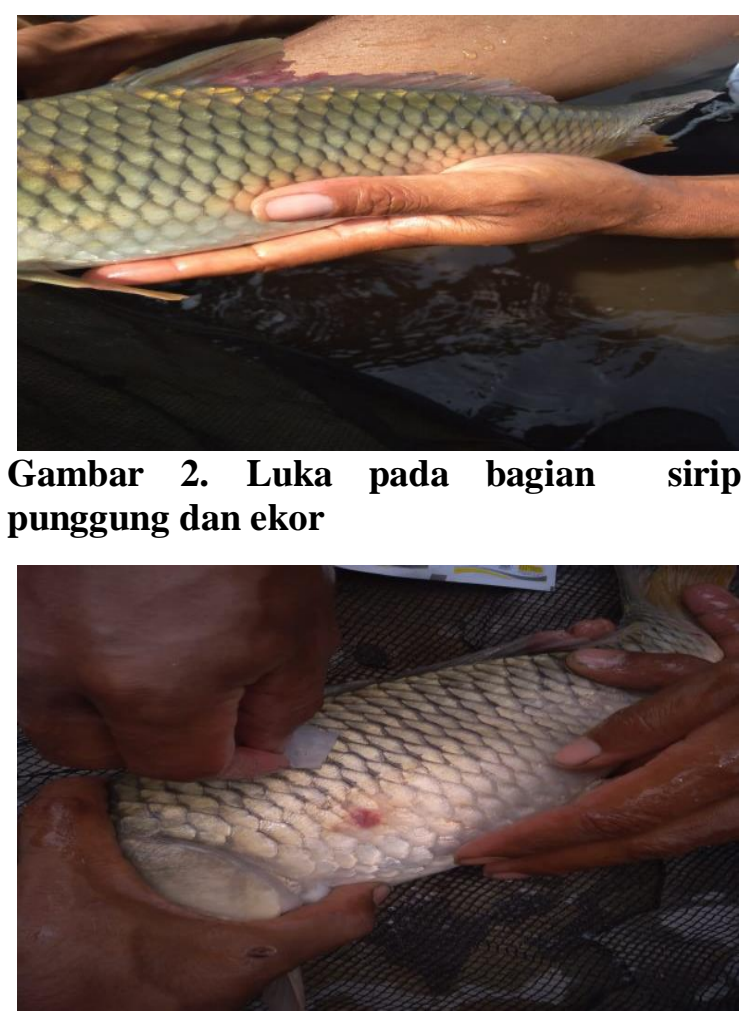

Gambar 3. Bercak merah pada permukaan tubuh

\section{PEMBAHASAN}

Berdasarkan pengamatan langsung di UPTD-BPBIAT dan pemeriksaan laboratorium parasit Argulus sp. dari 10 sampel ditemukan 9 ekor positif terinfeksi Argulus sp yang ditemukan di UPTD-BPBIAT Aikmel Kabupaten Lombok Timur berupa nimfa dengan ukuran panjang rata-rata $1,70 \mathrm{~mm}$, ukuran nimfa Argulus sp. berkisar 0,6 hingga berukuran 3-3,5 mm (Rusthon-Mellor, 1994 dalam Walker et al, 2001) nimfa Argulus sp. terlihat seperti Argulus sp. dewasa namun pada nimfa antena pada bagian chepalotorax belum berkembang.

Penyebab penyakit ini karena faktor lingkungan seperti kualitas air, faktor cuaca, dan pakan yang berlebihan yang dapat memicu timbulnya parasit sesuai dengan pernyataan Handajani dan Widodo (2010) mengatakan bahwa timbulnya parasit dipengaruhi oleh kepadatan ikan dalam kolam yang tinggi akan menyebabkan ikan mudah stress, Kualitas air yang buruk, pemberian pakan ikan yang berlebih dan perubahan iklim.

Ikan karper yang terinfeksi ektoparasit Argulus sp. merupakan induk ikan karper yang memiliki berat rata-rata 2-3,5 kg. Ikan karper yang tidak mengalami perubahan patologi atau terinfeksi merupakan ikan karper yang memiliki berat $5 \mathrm{~kg}$ sehingga tidak terjadi infeksi. Sufriyanto dkk (2013) mengatakan Tingkat serangan infeksi parasit Argulus sp. tergantung pada ukuran ikan dan jumlah parasit yang menyerang. Ikan karper dengan berat $5 \mathrm{~kg}$ memiliki pertahanan tubuh yang lebih besar hal ini dilihat dari kulit,lendir dan sisik, ikan dengan berat $5 \mathrm{~kg}$ cenderung memiliki ukuran sisik, lendir, dan kulit lebih tebal Bachtiar (2002) mengatakan kulit pada ikan berfungsi sebagai proteksi dari benturan, kotoran dan hama penyakit, selain itu lendir yang yang dihasilkan lebih banyak sehingga tidak mudah ditempati Argulus sp. Umumnya parasit lebih suka menghuni organ tubuh ikan jika organ tersebut mudah ditempati (Rohde, 1982).

Argulus sp. pada ikan Karper ditemukan pada bagian lendir, sirip, dan ekor. penelitian ini membuktikan bahwa parasit ini menyerang ikan pada bagian luar tubuh yaitu permukaan tubuh atau lendir,sirip dan ekor. Argulus sp. ditemukan pada bagian luar tubuh karena pada bagian permukaan tubuh merupakan bagian yang pertama kali kontak dengan lingkungan. Mulyana (2011) mengatakan kulit dan sisik ikan berperan dalam perlindungan mekanik terhadap invasi patogen melalui penebalan kutikula ataupun hiperflasia sel-sel malfigi. Produksi lendir yang berlebihan pada kulit ikan ini dapat mengindikasikan bahwa ikan tersebut sedang terinfeksi parasit (Haryono,dkk. 2016). Sirip dan ekor merupakan bagian yang terletak diluar dan kontak langsung dengan lingkungan maka bagian ini juga mudah terinfeksi parasit. Tingkat infeksi Argulus sp. juga tergantung ukuran ikan dan jumlah parasit yang menginfeksi.

Argulus sp. di UPTD-BPBIAT Aikmel secara visual tampak seperti kutu yang menempel pada permukaan tubuh ikan Karper (Cyprinus carpio L) terdapat luka, kerusakan bagian sirip dan ekor. Menurut Juniarsih (2017) hal ini terjadi karena Argulus sp. menyerang ikan dengan cara menempel dan menusuk pada tubuh inang dengan menggunakan stylet, parasit ini akan melepaskan zat anti koagulan setelah Argulus sp. menempelkan diri pada inang yang berfungsi untuk mencegah pembekuan darah. Argulus sp. menghisap darah inangnya menggunakan proboscis sehingga terjadi infeksi dan terjadi kerusakan jaringan sesuai dengan pernyataan irawan (2000). Hasil penelitian juga didapatkan satu ekor ikan 
dengan bobot badan $5 \mathrm{~kg}$ tidak mengalami perubahan patologi hal ini dikarenakan ukuran ikan yang lebih besar. Khoiron (2005) mengatakan bahwa perubahan patologi pada inang tergantung pada ukuran inang, intensitas dan infestasi dari daerah yang terserang.

\section{KESIMPULAN}

Kesimpulan dari deteksi ektoparasit Argulus sp. pada budidaya ikan Karper di UPTD- BPBIAT Aikmel didapatkan 9 positif terinfeksi dari 10 sampel.

\section{REFERENSI}

Handajani H \& Widodo W. 2010. Nutrisi Ikan. Malang: UMM Press.

Irawan, Agus. 2000. Menanggulangi Hama dan Penyakit Ikan. CV. Aneka. Solo. 82 hal

Juniarsih, A., G. Mahasri, Kismiyati. 2017. Infestasi Argulus Pada Ikan Mas (Cyprinus Carpio L) Di Pasar Kolam Tanah Dan Beton, Kecamatan Muntilan Dan Mungkid, Kabupaten Magelang. Journal Of Aquaculture And Fish Health, 6(2): 74-80

Khoiron,M. 2005. Gambaran Histopatologi Organ Sirip Ekor Ikan Maskoki Tosa (Carrasius aurratus) yang terinfestasi Argulus sp. Fakultas Kedokteran Hewan Universitas Airlangga.[SKRIPSI]

Komarudin. O. H. Supriyadi, I. Faturochman. 1987. Parasit Pada Beberapa Jenis Ikan Air Tawar. Parasitologi Indonesia Perkumpulan Pemberantasan Penyakit Parasit Indonesia, (1): 9-11

Mulyana. 2010. Parasit dan Penyakit Ikan. Buku Ajar. Bogor: Unida Press.

Ode. 2012. Argulus Ektoparasit pada Ikan. Bimafika, 4: 413-416

Bachtiar, Y. 2002. Mencemerlangkan Warna Koi. Agromedia Pustaka. Jakarta. Hal 74

Haryono, S. Mulyana, M.A. Lusiastuti. 2016. Inventarisasi Ektoparasit Pada Ikan Mas Koki (Carrasius auratus) Di Kecamatan Ciseeng- Kabupaten Bogor. Jurnal Milna Sains ISSN: 2407-9030: 2(2)
Rohde, K. 1982. Ecology of Marine Parasites. University of Queesland Press, Australia.

Wihardi. Y, I.Y. Yusanti, R.B.K. Haris. 2014. Feminisasi Ikan Mas (Cyprinus Carpio) Dengan Perendaman Ekstrak Daun- Tangkai Buah Tarung Cepoka (Solanum Torvum) Pada Lama Waktu Perendaman Berbeda. Jurnal Ilmu-Ilmu Perikanan Dan Budidaya Perairan 9(1): 23-28 